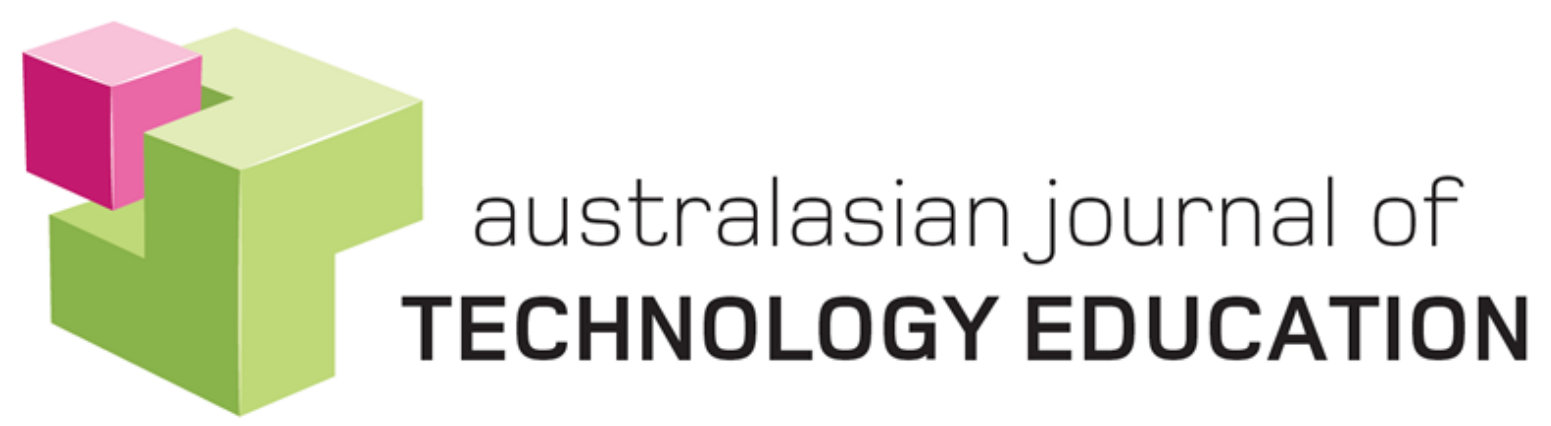

Editor: Professor P John Williams, University of Waikato, New Zealand

Consulting Editor : Professor Alister Jones, University of Waikato, New Zealand

Editorial board:

Prof Jacques Ginestié, Aix-Marseille Université, France

Prof Stephanie Atkinson, Sunderland University, England

Prof John Ritz, Old Dominion University, USA

Prof Marc de Vries, Delft University of Technology, Netherlands

Dr Wendy Fox-Turnbull, University of Canterbury, New Zealand

Prof Mishack Gumbo, University of South Africa

Prof Michael Hacker, Hofstra University, USA

Prof Jonas Hallstrom, Linkoping University, Sweden

Prof David Spendlove, University of Manchester, England

Prof Scott Warner, Millersville University, USA

The Australasian Journal of TechnologyEducation is a peer refereed journal, and provides a forum for scholarly discussion on topics relating to technology education. Submissions are welcomed relating to the primary, secondary and higher education sectors, initial teacher education and continuous professional development, and general research about Technology Education. Contributions to the on-going research debate are encouraged from any country. The expectation is that the Journal will publish articles at the leading edge of development of the subject area.

The Journal seeks to publish

- reports of research,

- articles based on action research by practitioners,

- literature reviews, and

- book reviews.

Publisher: The Technology, Environmental, Mathematics and Science (TEMS) Education Research Centre, which is part of the Faculty of Education, The University of Waikato, publishes the journal.

Contact details: The Editor, AJTE, pjohn.williams@curtin.ecu.au

Cover Design: Roger Joyce

This journal provides immediate open access to its content on the principle that making research freely available to the public supports a greater global exchange of knowledge.

ISSN: 2382-2007 


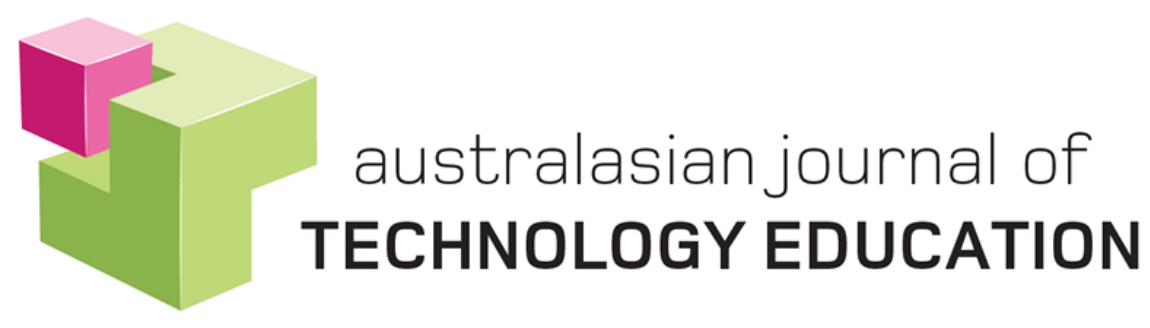

\title{
Integrating Digital Technologies into The New Zealand Curriculum: Future-focused and technological ways of thinking
}

\author{
Elizabeth Reinsfield
}

\begin{abstract}
The ability to function in a technologically mediated world is a global priority. In New Zealand, there has been a recent curriculum revision, which emphasises the role of Digital Technology, and there is an assumption that this will equate to the use of digital technologies for learning. This change highlights a need for students to develop their digital fluency but also engage with learning that encourages them to become creators of digital outcomes. To enable this process, students need to be encouraged to develop their technological and technical ways of thinking. This article reports on qualitative research to describe how one secondary school teacher enacted digital technology aspects of the technology curriculum. Data were collected through observational and self-report methods. The findings indicate that technological ways of thinking are suited to the enactment of technology education, when situated within authentic, personally meaningful, or problem-based contexts for learning.
\end{abstract}

\section{Key words}

Digital technology; digital technologies for learning; technological thinking; technologically mediated.

\section{Introduction}

According to the The Economist Intelligence Unit (2017), New Zealand is leading the way in preparing students for their future in a technologically mediated world. New Zealand's success is attributed to an education system that emphasises the development of future-focused skills, as enacted through effective teaching and the use of digital technologies. The emergence of Innovative Learning Environments (ILE's) has led to a focus on the ways in which teachers develop their pedagogical responses to accommodate students' learning needs. School structures are changing because of the increasing need for flexibility in the way that the school-based curriculum is enacted (Leggat, 2015). There has been a recent revision to the New Zealand Curriculum (MoE, 2017), which provides an opportunity to teach from a future-focused perspective that is inclusive of digital pedagogies, learner-centred in nature, and designed to emphasise critical and creative thinking (Organization for Economic Cooperation and Development (OECD), 2013). Technology education is a means to enable such practice. This article reports findings from one teacher in the Technology Education in New Zealand: Secondary School Innovative Learning Environment (TENZSILE) project, which explored how four 
teachers were using digital technologies in their classrooms. There is a deliberate focus on the effective practice of Georgia, and the ways that she encouraged students (aged between 11 and 13) to engage with different ways of thinking when learning about technology education.

\section{Technology education curriculum in New Zealand}

The technology education curriculum in New Zealand consists of three strands - Technological Practice (TP), Technological Knowledge (TK) and the Nature of Technology (NoT). The Technological Practice strand focuses on the processes underpinning the development of outcomes and systems. Technological Knowledge is a means to support students' contextual understanding and inform their practice. The Nature of Technology strand situates students' learning to consider their practice within global, local, past, current, and future societal contexts. Learning in technology should be organised so that students can explore an authentic issue or real-world problem (Fox-Turnbull, 2006; Reinsfield, 2018a).

\section{Digital technology}

The 2007 iteration of the New Zealand Curriculum (Ministry of Education, 2007) has been recently revised to emphasise the role of Digital Technology in students' learning. There are now five technological areas which can span all three strands of the technology curriculum. These technological areas are:

1) designing and developing materials (e.g., textiles) outcomes;

2) designing and developing processed (e.g., biotechnology or food) outcomes;

3) design and visual communication;

4) computational thinking for digital technologies; and

5) designing and developing digital outcomes (Ministry of Education, 2017a).

The aim of this revision was to emphasise the need for a coherent curriculum as an entitlement for all young people in New Zealand (Digital Technology Hui, personal communication, October 2, 2018 ). The intention is that this will occur through the development of students' capabilities as a result of their engagement with disciplinary knowledge, and skills in critical inquiry and active learning from a variety of perspectives. There is a risk that as a result of this recent curriculum revision however, that practitioners' past issues with the technology curriculum might be perpetuated, that is - digital technology might become solely about skills development or the use of digital tools rather than a means to engage with purposeful intervention by design. This recent revision presents a new challenge for technology teachers, in terms of how, in their classrooms, they manage the traditional perceptions of the subject, interpret the curriculum, and respond to the changing context of global, social, and technological need (Reinsfield, 2018a).

Digital technology is located within the technology education part of the curriculum, which emphasises the critical and creative thinking underpinning students' technological practice (Reinsfield, 2018b). It is asserted here, that to design and develop a digital outcome and enable students to become digital creators (people who can create a digital artefact or content for an identified user), learners will need to be supported through different stages of capability (see Figure 1). 


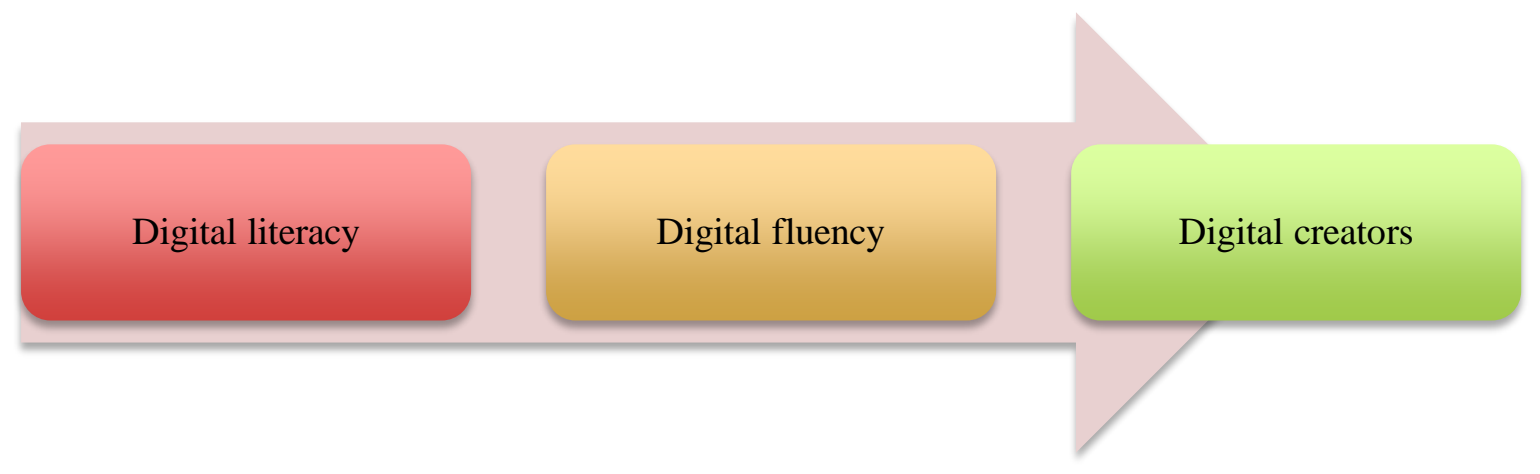

Figure 1. The stages towards becoming a digital creator

Digital literacy is defined here as the skills and proficiency in the use of digital tools (e.g. software or platforms for learning) - users who are digitally literate can assimilate information, and evaluate fitness for purpose (Glister \& Glister, 1997; Jones \& Hafner, 2012; Lankshear \& Knobel, 2011; Thorne, 2013). A digitally literate student knows how to use a digital tool to enable their technological practice. Digital fluency suggests a higher level of capability, where the student makes informed decisions about the type of digital tool they wish to use to enable their technological practice and the development of a digital outcome (Attwell, 2007; Ministry of Education, 2017b; Prensky, 2012; Wenmoth \& CORE Education, 2016; White, 2013). A student can demonstrate their digital fluency within the two new technological areas of digital technology, in other areas of technology education, or elsewhere in the curriculum if teachers advocate for such learning.

Students can be digital creators across curriculum areas, including technology education (e.g., Chung, 2006). In technology education however, digital creators might develop content for online platforms, in text, image, audio, or video form. To be a digital creator will require students to be aware of a diverse range of pertinent factors influencing their design and development, which can be informed through their technological practice, evolving technological knowledge, and as a result of their understanding of the nature of the context in which their outcome or system is to be located.

\section{Use of digital technologies for teaching}

In New Zealand, teachers are increasingly expected to model the use of digital pedagogies in their practice, with a view to fostering students' digital literacy (MoE, 2016a, 2016b). Such practice is distinct from the role of Digital Technology within the technology curriculum, which aims to support students to engage with the type of technological thinking necessary to inform, critique, and create digital outcomes to address an identified need (MoE, 2017a). The revised curriculum outlines that learning about Digital Technology should "significantly contribute to students developing the knowledge and skills they need as digital citizens and as users of digital technologies across the curriculum” (MoE, 2017b, p. 3). To encourage learners to become digitally fluent and creators of new knowledge however, they need to be exposed to learning that explores the nature of the relationship between technology and society (Reinsfield, 2018b). Such a focus is appropriate because learners can engage with:

- technology from a historical perspective or as socially constructed in nature; 
Reinsfield: Integrating Digital Technologies into The New Zealand Curriculum: Future focused and technological ways of thinking

- the development of technologies and techniques that apply in our constructed world, to encompass the processes, ways of thinking, and organisation of socio-technological contexts;

- generic contexts which transcend specialist areas of technology (like textiles and design and visual communication); and

- dynamic learning to enable participation in a developing global and digital community (Dakers, 2016; de Vries, 2005; Wallace \& Hasse, 2014).

To encourage students to become digital creators, teachers need to be confident in their own use of digital technologies. To exploit the use of digital technologies in technology education, teachers also need to understand how key curriculum concepts should be taught. For example, the curriculum notion of design brief development can be used to support students' understanding of the ways they can develop a technological outcome according to an identified user's needs (Ministry of Education, 2007).

This article reports upon research that explored how one teacher deliberately managed her environment for learning to respond to students' interests, and to teach the technological area of designing and developing a digital outcome in the technology curriculum. Technological thinking is presented as "more likely to aid enactment of a range of pedagogical approaches and learning outcomes that are reflective of the intent of the New Zealand curriculum" (Reinsfield \& Williams, 2017, p. 11).

The New Zealand Curriculum (Ministry of Education, 2017a) provides a means for teachers to plan and structure students' future-focused conceptions of technology education. To make meaning of and then enact the curriculum, teachers will inevitably draw upon existing knowledge and seek to establish new understanding (Reinsfield, 2018a). Some teachers may only emphasise technical knowledge, the how to, in their classroom, others encompass both technical and technological thinking. When developing a website, for example, a combination of technical and technological thinking would accommodate students' understanding of how to design (in negotiation with a user) to develop an outcome which is fit for purpose. The technological thinking would incorporate why the student developed their website to address their user's needs; the technical thinking would be what they needed to know and do to enact their plan.

Technical thinking aligns with a more traditional conception of technology education - where ideas and outcomes are developed through a focus on using hand tools and equipment (Hansen, 2008). Technological thinking is presented here as being a more expansive approach to the subject, which is future-focused in nature and can exploit technical thinking as a means to enable innovative responses and the use of resources in purposeful and authentic ways, to respond to an identified issue (Reinsfield, 2018a; Reinsfield \& Williams, 2017). The next section identifies findings that show how one teacher (Georgia) enabled differing ways of student thinking in her classroom.

\section{Research design}

The TENZSILE project used an interpretivist framework. The research had a deliberate focus on four teacher's circumstances, from a socio-cultural perspective. From a socio-cultural perspective, teachers' expertise develops over time in a social context, through the acquisition of knowledge and engagement in discourse, norms, and the practices of a community (Fuhrer, 1993; Lave, 1997; Lave \& Wenger, 1991). This research was designed to acknowledge that teachers' ways of 
Reinsfield: Integrating Digital Technologies into The New Zealand Curriculum: Future focused and technological ways of thinking

thinking about technology education are likely to connect to their lived experiences, but will also be mediated by their socio-cultural context. The pilot research was based in one school, to further explore findings from my $\mathrm{PhD}$ research.

Georgia was purposefully selected because she co-taught the curriculum in an integrated manner, and was known in her Innovative Learning Environment as being an effective practitioner. During an initial meeting, one lesson per week was nominated as a suitable time to be observed teaching.

The data were collected through a semi-structured interview, lesson observations and teacher reflections. The first interview (of two) provided a baseline understanding of Georgia's perceptions and professional practice (Creswell, 2012). Lesson observation was deliberately chosen because it was deemed as an effective way of yielding authentic data to represent the participants' reality (Lincoln \& Guba, 1985). To accurately represent the participants' inner worlds, it was important to consider the potential Hawthorne Effect during observations, where the teacher might change behaviour because she was being watched (Kuper, Reeves, \& Levinson, 2008). Whilst presence during lesson observations might have affected the participants' actions initially, the adoption of a non-participatory role meant that teachers naturally immersed themselves in their classroom practice.

Once a fortnight, each teacher was sent an edited video of observed lessons and asked to review then reflect on their teaching (Maclean \& White, 2007). Questions were provided to guide the reflection process, and the teacher was asked how she accommodated students' academic or social needs within her classroom, how she had deliberately used a range of resources, and how this enabled her intended learning focus. These reflections were also analysed as data.

\section{Data analysis}

Data from teacher interviews were transcribed and analysed using thematic analysis to allow for the extraction of meaning and reporting of emerging knowledge (Javadi \& Zarea, 2016). Deductive coding was used with all data, to establish a frame for analysis and determine the emerging themes, according to the research questions, with a view to extrapolate implicit and explicit themes within the data (Bazeley, 2007; Guest, MacQueen, \& Namey, 2012). The research questions asked:

1. What pedagogical strategies do secondary teachers use when they are motivated to teach the curriculum in a future-focused way?

2. How can teachers' foster learner-centred approaches to pedagogy within an Innovative Learning Environment and integrated curriculum?

Figure 2 illustrates the emerging themes, which were then aligned with the research questions. 

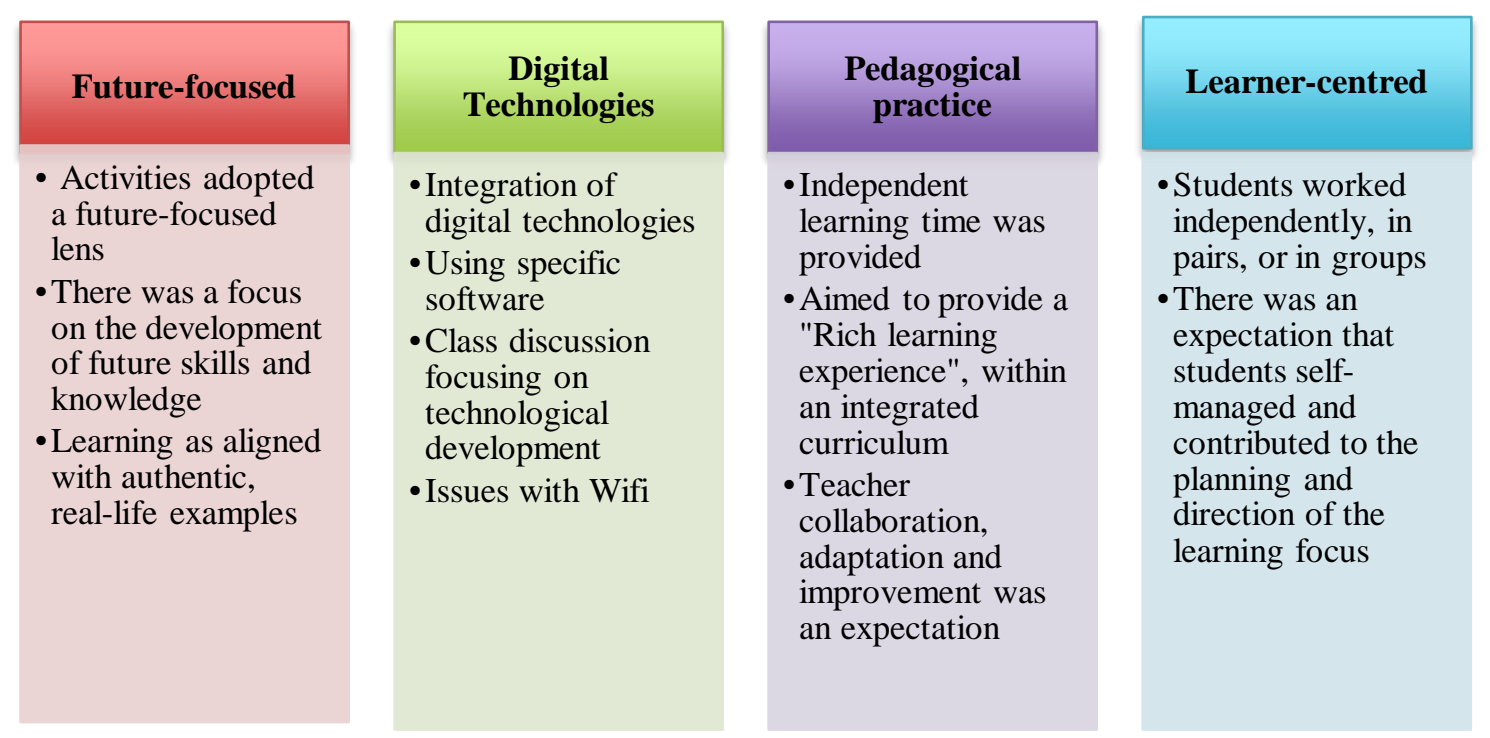

Figure 2. The emerging themes from Georgia's TENZSILE data

\section{Findings and discussion}

The next section will report findings from Georgia, the Digital technology teacher, to exemplify the ways that she deliberately encouraged both technical and technological thinking in her classroom. This is pertinent because the recent revision to the curriculum has increased practitioner interest in the ways that technology education can be taught to encourage students to critique the nature of digitally mediated technological development. This section is organised according to the aims for learning, the strategies and encouraged ways of thinking, and consequent discussion about developing students' future focused capabilities in technology education.

When describing the context for learning, Georgia identified that the focus of her teaching was to develop students' understanding of the newly conceived learning progression outcomes for the digital technology area of the technology curriculum. This states that students should "understand that digital devices impact on humans and society and that both devices and their impact change overtime” (Technology Online, n.d., para 1). The move towards learning progression outcomes in the digital technology area of the curriculum is potentially confusing for technology teachers because there is a need for them to assess learning differently to the rest of the learning area. Other technological areas use Achievement Objectives to determine student understanding. This signals a change in the Ministry of Education's focus in New Zealand, to assess how students have developed their understanding over a period of time, rather than at a single "point in time."

During the data collection phase of the research, Georgia was working with a teacher of English to deliver an integrated curriculum. Georgia's key aims for the term were to integrate digital technologies into her teaching, to enable students to use them, and learn through their use (Interview One). The learning focus was to explore the evolution of technology over the last 35 years to see how it had advanced in such a short time. Georgia wanted to emphasise that although we can make predictions, no-one knows exactly what changes will occur in the future (Reflection One). 
Reinsfield: Integrating Digital Technologies into The New Zealand Curriculum: Future focused and technological ways of thinking

Georgia understood the need to develop students' technological literacy as part of her professional role; to "develop a broad technological literacy that will equip [students] to participate in society as informed citizens and give them access to technology related careers" (MoE, 2007, p. 32). Her plan made connections with the intent of the technology curriculum, and in particular, the Nature of Technology strand, which outlines that learning can focus on the:

...impact of technology on societies and the environment ... to explore how developments and outcomes are valued by different peoples in different times. As they do so, they come to appreciate the socially embedded nature of technology and become increasingly able to engage with current and historical issues and to explore future scenarios (Ministry of Education, 2017a, p. 3).

Class discussions centred on the concepts from both English and technology education learning areas of the curriculum. During the first few weeks, students learnt about the novel ${ }^{1}$ Ender's Game (Card, 1994), and identified the technologies they recognised. These included wearable technology, motion detecting doors, microchips, artificial intelligence, and drones. Examples of technology from 1985 (such as mobile phones, floppy disks, gaming machines, and music tapes) were then provided for critique. Students were asked to predict how technology might develop by 2118, write down their ideas, discuss these with their peers, review the idea, and draw it. From there, students developed a science fiction book and were asked to invent a visual technology suited to the year 2118. These activities encouraged students to critique the why of technological development, so were engaging in technological thinking.

Georgia explained that she loved this context for learning because students could “...think outside the box... there are no right or wrong answers, and students can be as creative or 'out-there' as they like - it's encouraged in fact." Georgia explained that one student "looked into 3 Dimensional printing of organs, so we wouldn't need donors; another thought holograms would go to work and we could operate them from the comfort of our home!” (Reflection One).

Computer software such as Pear Deck, Sketch-Up and Tinkercard were offered as a means to support technical thinking - for students to engage with digital tools and develop their digital literacy. Pear Deck was used with a view to encouraging students to take an active role in their learning. Such thinking aligns with learner-centred pedagogies, which can be traced back to Dewey, who theorised that the nature of education should be responsive to the school's students and community (Brough, 2008). From Dewey's perspective (1936, 1986, 2004), schools should be democratic environments where learners are enabled to work together to solve real-life issues in order to become contributing members of society.

The challenge for teachers with a learner-centred approach is that it is likely to require them to be responsive to, and facilitative of, the development of knowledge and skills as they emerge in the classroom. Such an approach is therefore dependent upon practitioners having the confidence, motivation, knowledge, and interest to accommodate a range of differing learning opportunities, from a variety of disciplines, in order to respond to students' interests (McCombs \& Whisler, 1997; Onchwari, Onchwari \& Keengwe, 2009; Tabulawa, 2003; Windschitl, 2002). A futurefocused and learner-centred approach to technology education provides the opportunity to negotiate how learning is occurring in the classroom. Teachers are then required to guide the

\footnotetext{
1 The child in this story is selected to save the world from imminent destruction. He wears a technological device to monitor his actions throughout his journey.
} 
Reinsfield: Integrating Digital Technologies into The New Zealand Curriculum: Future focused and technological ways of thinking

learning to ensure that there are opportunities for the curriculum concepts to be naturally addressed (Reinsfield, 2018a).

Georgia's plan for learning encouraged the development of students' technological thinking. Sketch-Up and Tinkercard were a means to enable the development of a prototype, which aligned with the design and developing a digital outcome area of the technology education curriculum (Ministry of Education, 2017a). In the final interview, Georgia was excited to talk about her learning focus with a new class, stating "I love [that] with coding it teaches critical thinking because it's rarely the computer [that is] causing things to go wrong - it's because you have put in the wrong code" (Final Interview).

\section{Conclusions}

The revision to the curriculum presents potential for technology education teachers to enable students' learning from a range of future-focused perspectives. It is a pertinent time for research to explore what teachers are already doing to enact the curriculum in a learner-centred way. The TENZSILE research confirmed that it is imperative for teachers to be cognisant of the distinction between the use of digital technologies to mediate learning, and the nature of digital technology, as it is conceptualised within the curriculum - intended to facilitate students' understanding of the nature and development of technological products. Both of these concepts have merit in supporting students' capability to function in a future-focused and technologically mediated world.

\section{Affiliations}

Elizabeth Reinsfield

Lecturer

Te Hononga Curriculum and Pedagogy

University of Waikato: Te Whare Wānanga o Waikato

elizabeth.reinsfield@waikato.ac.nz

\section{References}

Attwell, G. (2007). Personal learning environments - The future of e-learning? eLearning Papers, 2(1), 1-8. Retrieved from https://www.researchgate.net/publication/228350341_Personal_Learning_Environmentsthe_future_of_eLearning

Bazeley, P. (2007). Qualitative data analysis with NVivo qualitative project book. Thousand Oaks, CA: Sage.

Brough, C. (2008). Student-centred curriculum integration and the New Zealand Curriculum. Set: Research Information for Teachers, (2), 16-22.

Card, O. S. (1994). Ender's Game. New York, NJ: Tom Doherty Associates.

Chung, S. K. (2006). Digital storytelling in integrated arts education. The International Journal of Arts Education, 4(1), 33-50.

Creswell, J. W. (2012). Collecting qualitative data. Educational research: Planning, conducting, and evaluating quantitative and qualitative research. Boston, MA : Pearson.

Dakers, J. (Ed.). (2016). New frontiers in technological literacy: Breaking with the past. New York, NY: Palgrave MacMillan.

de Vries, M. (2005). Teaching about technology: An introduction to the philosophy of technology for non-philosophers. Dordrecht, The Netherlands: Springer. 
Reinsfield: Integrating Digital Technologies into The New Zealand Curriculum: Future focused and technological ways of thinking

Dewey, J. (1936). Characteristics and characters: Kinds and classes. The Journal of Philosophy, 33(10), 253-261. Retrieved from http://www.jstor.org/stable/2016969

Dewey, J. (1986). Experience and education. The Educational Forum, 50(3), 241-252. Retrieved from https://doi.org/10.1080/00131728609335764

Dewey, J. (2004). Democracy and education. Mineola, NY: Dover.

Fox-Turnbull, W. (2006). The influences of teacher knowledge and authentic formative assessment on student learning in technology education. International Journal of Technology and Design Education, 16(1), 53-77. doi:10.1007/s10798-005-2109-1

Fuhrer, U. (1993). Behaviour setting analysis of situated learning: The case of newcomers. In S. Chaiklin and J. Lave (Eds.), Understanding practice: Perspectives on activity and context. (pp. 179-211). Cambridge, UK: Cambridge University Press.

Glister, P., \& Glister, P. (1997). Digital literacy. New York, NY: Wiley Computer.

Guest, G., MacQueen, K. M., \& Namey, E. E. (2012). Validity and reliability (credibility and dependability) in qualitative research and data analysis. Applied Thematic Analysis. London, England: Sage.

Hansen, R. E. (1996). Does integrating technology, science, and mathematics improve technological problem solving? A quasi-experiment. Journal of Technology Education, 8(1), 5-15.

Javadi, M., \& Zarea, M. (2016). Understanding thematic analysis and its pitfall. Journal of Client Care, 1(1), 33-39.

Jones, R. H., \& Hafner, C. A. (2012). Understanding digital literacies: A practical introduction. New York, NY: Routledge.

Kuper, A., Reeves, S., \& Levinson, W. (2008). An introduction to reading and appraising qualitative research. British Medical Journal, 337(7666), 404-407.

Lankshear, C., \& Knobel, M. (2011). Literacies: Social, cultural and historical perspectives. New York, NY: Peter Lang.

Lave, J. (1997). The culture of acquisition and the practice of understanding. In D. Kirshner \& A. Whitson (Eds.), Cultural Psychology: Social, semiotic, and psychological perspectives (pp. 17-36). Mahwah, NJ: Lawrence Erlbaum Associates.

Lave, J., \& Wenger, E. (1991). Situated learning: Legitimate peripheral participation. York, England: Cambridge University.

Leggat, P. (2015). Modern learning environments, $21^{\text {st }}$ Century learning and curriculum and future-focused learning (Sabbatical report). Retrieved from https://www.google.co.nz/search?q=Leggat+modern+learning+environments\&oq=Legg at+modern+learning+environments\&aqs=chrome..69i57j69i60.13727j0j8\&sourceid=ch rome\&ie=UTF-8

Lincoln, Y. S., \& Guba, E. G. (1985). Naturalistic inquiry. London, England: Sage.

Maclean, R., \& White, S. (2007). Video reflection and the formation of teacher identity in a team of pre-service and experienced teachers. Reflective Practice, 8(1), 47-60.

McCombs, B. L., \& Whisler, J. S. (1997). The learner-centered classroom and school: Strategies for increasing student motivation and achievement. San Francisco, CA: JosseyBass.

Ministry of Education. (MoE.). (2007). The New Zealand Curriculum. Wellington, New Zealand: Learning Media.

Ministry of Education. (MoE.). (2016a). Digital technology to become part of the New Zealand Curriculum and Te Marautanga o Aotearoa. Retrieved from https://education.govt.nz/news/digital-technology-to-become-part-of-the-new-zealandcurriculum-and-te-marautanga-o-aotearoa/ 
Reinsfield: Integrating Digital Technologies into The New Zealand Curriculum: Future focused and technological ways of thinking

Ministry of Education. (MoE.). (2016b). Four year plan 2016-2020. Retrieved from https://education.govt.nz/ministry-of-education/publications/four-year-plan-and-statementsof-intent/four-year-plan-2016-2020/

Ministry of Education. (MoE.). (2017a). Digital technologies: Hangarau Matihiki. Wellington, New Zealand. Retrieved from https://education.govt.nz/assets/Documents/Ministry/consultations/DTconsultation/DTCP1701-Digital-Technologies-Hangarau-Matihiko-ENG.pdf

Ministry of Education. (MoE.). (2017b). Enabling e- learning. Retrieved from http://elearning.tki.org.nz/Teaching/Digital-fluency

Onchwari, G., \& Onchwari, J. \& Keengwe, J. (2009). Technology and student learning: Toward a learner-centered teaching model. Association for the Advancement of Computing in Education Journal, 17(1), 11-22.

Organisation for Economic Cooperation and Development. (OECD.). (2013). Innovative learning environments. OECD Publishing. Retrieved from http://dx.doi.org/10.1787/9789264203488-en

Prensky, M. (2012). From digital natives to digital wisdom: Hopeful essays for 21st century learning. California, CA: Sage.

Reinsfield, E. (2018a). The potential for a future-focused curriculum in New Zealand: The perceptions and practice of six secondary school technology teachers (Doctoral thesis). Retrieved from https://hdl.handle.net/10289/11939

Reinsfield, E. (2018b, October). Future-focused approaches to the New Zealand Curriculum: An integrated approach. Paper presented at the AATE Conference. Hamilton, New Zealand.

Reinsfield, E., \& Williams, P. J. (2017). New Zealand secondary technology teachers' perceptions: Technological or technical thinking? International Journal of Technology and Design Education, 1-13. https://doi.org/10.1007/s10798-017-9418-z

Tabulawa, R. (2003). International aid agencies, learner-centred pedagogy and political democratisation: A critique. Comparative Education, 39(1), 7-26. https://doi.org/10.1080/03050060302559

Technology Online (n.d.). Designing and developing digital outcomes: Progress outcomes, exemplars, and snapshots. Retrieved from http://technology.tki.org.nz/Technology-in-theNZC/DDDO-Progress-outcomes-exemplars-and-snapshots/(tab)/PO2

The Economist Intelligence Unit (2017). Worldwide Educating for the Future Index: A benchmark for the skills of tomorrow. Retrieved from https://dkf1ato8y5dsg.cloudfront.net/uploads/5/80/eiu-yidan-prize-educating-for-the-futurewp-final.pdf

Thorne, S. L. (2013). Digital literacies. In M. R. Hawkins (Ed.), Framing languages and literacies: Socially situated views and perspectives (pp. 192-218). New York, NY: Routledge.

Wallace, J., \& Hasse, C. (2014). Situating technological literacy in the workplace. In J. Dakers (Ed.), New frontiers in technological literacy (pp. 134-164). New York, NY: Palgrave Macmillan.

Wenmoth, D., \& CORE Education, (2016). Designing authentic assessment challenges for distance learners. Paper presented at DEANZ2016. University of Waikato. Hamilton, New Zealand.

White, G. K. (2013). Digital fluency: Skills necessary for learning in the digital age. Melbourne, Australia: Australian Council for Educational Research.

Windschitl, M. (2002). Framing constructivism in practice as the negotiation of dilemmas: An analysis of the conceptual, pedagogical, cultural, and political challenges facing 
Reinsfield: Integrating Digital Technologies into The New Zealand Curriculum: Future focused and technological ways of thinking

teachers. Review of Educational Research, 72(2), 131-175.

https://doi.org/10.3102/00346543072002131 